\title{
Pandemiens fortællinger om sygeplejen
}

Trine Schifter Larsen ${ }^{1}$

Nina Halberg 2

${ }^{1}$ Center for Sundhedsfremmeforskning RUC samt Den Sygeplejefaglige Forsknings- og Udviklingsenhed, Ortopædkirurgisk afdeling, Amager og Hvidovre tslarsen@ruc.dk

${ }^{2}$ Den Sygeplejefaglige Forsknings- og Udviklingsenhed, Ortopædkirurgisk afdeling, Amager og Hvidovre

nina.halberg@regionh.dk

Larsen, Schifter Trine \& Halberg, Nina. (2020). Pandemiens fortællinger om sygeplejen. Tidsskrift for Forskning i Sygdom og Samfund nr 33, 197-204

\section{Sygeplejeidentitet i forandring?}

Som forholdsvis nyuddannet sygeplejerske i 2005 havde jeg en samtale med min afdelingssygeplejerske, som er blevet hængende hos mig og er dukket op flere gange i mit hoved siden. Hun sad foran mig på personalekontoret med vagtplanen, som hun igen havde vanskeligheder med at få til at gå op. Der var kommet en sygemelding til aftenvagten og hun kunne ikke få nogen til at komme ind og tage den. Hun er på det tidspunkt en kvinde omkring 60 år, og jeg omkring de 30 år og mor til to mindre børn. Hun syntes, der var sket en forandring i måden sygeplejersker prioriterede deres arbejde på, hun sagde: »da min mand friede til mig, sagde jeg ' $j a$ ', men understregede, at han skulle vide, at han giftede sig med en sygeplejerske". Hermed mente hun, at arbejdet som sygeplejerske kom i første række - før familien - og at hvis der var brug for hende, så smed hun, hvad hun havde i hænderne, 
eller det var i hvert fald det, jeg tænkte, hun gerne ville formidle til mig. Jeg kan huske, at jeg forundret over hendes pointe om, at hendes kommende mand skulle forstå, at dét at være gift med en sygeplejerske betød, at han, og den familie de måske fik sammen, kom i anden række, og at det var en præmis for, at hun kunne indgå i et ægteskab med ham. Jeg forstod, at det at være sygeplejerske var en del af hendes identitet på en helt anden måde end for mig. At sygeplejerske ikke var en del af min identitet på den måde, som det var for hende, kan selvfølgelig også hænge sammen med, at jeg allerede et år efter, at jeg var uddannet sygeplejerske, overvejede at læse noget andet. Men jeg blev alligevel slået af den tilgang til sygepleje, hun præsenterede for mig, som en altopofrende livsform og identitet, et 'kald'? At min familie altid ville komme i første række fremfor mit arbejde som sygeplejerske, var ikke noget jeg oplevede, at jeg var alene med blandt mine sygeplejekolleger - også dem, som var mere sikre på deres valg af profession. De smed ikke uden videre, hvad de havde i hænderne midt i børnefødselsdagen lørdag eftermiddag og ilede på hospitalet, hvis der var sygdom blandt kollegerne. Selvom mange havde valgt sygeplejen ud fra et ønske om et meningsfuldt arbejde, hvor man meget konkret oplever at bidrage og hjælpe andre mennesker, så var sygepleje et arbejde, dog med anderledes arbejdsvilkår end meget andet arbejde, men ikke en altopofrende livsform. Så hun havde jo ret, hvis hun oplevede, at hendes generation af sygeplejersker generelt havde det som hende, og 'min generation' prioriterede anderledes.

Og hvorfor kommer hendes ord tilbage til mig nu, og hvad har de med pandemien at gøre? Det gør de, fordi vi med pandemien retter blikket mod sygeplejerskerne, som i disse måneder beskrives som både 'engle' og 'helte', som vi hylder for deres engagement. De sættes ind i en sensationsfortælling, hvor de er soldater, der ofrer deres liv, i en krig mod hele verdens fælles fjende. Men hvordan identificerer sygeplejerskerne sig med de fortællinger, som pandemien producerer om sygeplejen? Og hvad kan både omverdenens forventninger og håb til sygeplejen og denne pludselige heltedyrkelse samt sygeplejerskernes respons herpå fortælle os om moderne sygeplejeidentitet? Det vil vi i det her essay prøve at svare på.

\section{Feltstudie på et COVID-afsnit}

Pludselig i starten af marts blev halvdelen af den bygning, som Klinisk Forskningsafdeling på Amager og Hvidovre Hospital er en del af, indtaget af klinisk personale og omdannet til COVID-podeklinik. Nogle få dage senere var beskeden 
til os forskningsmedarbejdere: »Vi lukker ned for alle aktiviteter, som ikke er livsnødvendige, og I skal arbejde hjemmefra fra $i$ dag«. Det var dagen før hele Danmark blev lukket ned.

I den første tid arbejdede vi hjemmefra som så mange andre. Vi arbejdede med vores artikler, fondsansøgninger og projektplanlægning, mens vores kliniske kolleger skulle til at passe COVID-patienter. Vi er tre forskere, som har en sygeplejefaglig baggrund, og vi begyndte at overveje, hvordan vi kunne hjælpe dem. Vi fik mulighed for at hjælpe til på et COVID- afsnit som 'runnere', hvor vi hentede udstyr til sygeplejepersonalet på isolationsstuerne. Samtidig fik vi mulighed for at udføre et feltstudie. Fra denne position som 'runnere' udførte vi således deltagerobservationer, og da afsnittet efter tre måneder lukkede ned igen, lavede vi fokusgruppeinterviews med plejepersonalet, som havde plejet COVID-patienterne.

Da jeg på min første vagt ankommer til afsnittet, kan jeg ikke komme ind. Mit personalekort virker ikke til lige denne dør. Der er adgang forbudt skilte og et stort COVID-skilt med røde og sorte bogstaver på døren. Det er altså ikke enhver, der kan få adgang. Jeg får vinket en medarbejder hen til døren, som lukker mig ind, efter jeg har fortalt, at jeg skal være 'runner' i aftenvagten. Da jeg træeder ind på afsnittet, slår det mig, at den på mange måder ser ud og fornemmes som et hvilken som helst andet hospitalsafsnit, trods det dramatiske indtryk som stop- og COVID-skilte efterlod i mig. Det er i begyndelsen af april, og Danmark er lukket ned. Jeg har kun været sammen med min familie, min mand og vores tre børn i løbet af de sidste 14 dage. Men her på afsnittet summer det af aktivitet, og her er mange mennesker sammen - også på kontorerne. Ved næste øjekast kan jeg godt fornemme forskellen fra et 'almindeligt sengeafsnit' og dette sengeafsnit. Ud for hver stue står en vogn med skuffer og et metalbord med hjul. En sygeplejerske, som er på vej ind på en af stuerne, åbner en skuffe på vognen. Hun tager en blå dragt udenpå sin kittel, og åbner en ny skuffe. Hun tager noget, der ligner fyrværkeribriller op, et mundbind og handsker i størrelse medium. Hun tager kittel, briller, mundbind og handskerne på. Hun står lidt. Måske tænker hun på, om hun har det, hun skal bruge, for når først hun er derinde, kan hun ikke gå ud igen uden at skulle tage alle værnemidlerne af og nye på igen. Måske gennemgår hun med sig selv, hvad det er, hun skal hos patienten, eller også sunder hun sig lige lidt, inden hun skal derind. Det kan tage lang tid, før hun kommer ud igen. Alt tager længere tid end vanligt. Der går lidt tid, så stikker hun hovedet ud ad døren og kigger lidt omkring, vinker til én længere nede ad gangen, som står ved en vogn udenfor en stue og fra rullevognen tager briller, isolationskitler, éngangsblodtryksmanchetter, afspritningsservietter og putter i skufferne på vognen. Hun 
har også hospitalsuniform på, men en grøn trafikvest udenpå. På ryggen står der 'runner'. Hun får øje på sygeplejersken, der vinker fra døren nede ad gangen. Hun går med raske skridt ned ad gangen mod sygeplejersken. De taler kort. Sygeplejersken lukker døren og 'runneren' vender rundt og går lidt tilbage ad gangen og åbner et skab, kigger lidt, og trækker så en skuffe ud forneden i skabet. Hun tager en pakke med éngangsskumklude ud og tager endnu en pakke. Med de to pakker skumklude går hun tilbage til stuen, hvor sygeplejersken før stak hovedet ud. Hun kigger gennem ruden ved siden af døren ind til stuen, og får kontakt med sygeplejersken, som åbner døren lidt. Hun holder yderst på kanten af den ene pakke med skumklude, så sygeplejersken kan tage imod pakken fra den anden side med sin handskede hånd. På den måde rører deres hænder ikke hinanden, og 'runneren' er fortsat 'ren'. På samme måde rækker hun den anden pakke skumklude til sygeplejersken. Døren lukkes, og hun går tilbage til sit rullebord og fortsætter med at fylde op i vognene udenfor stuerne. Snart ringer en klokke et sted fra. Hun kigger op, og kan se på displayet i loftet på gangen, at det er fra stue 16. Det er ovre på den anden gang. Hun går derover, kigger ind gennem ruden ved døren, og et plejepersonale åbner døren, siger noget, og hun går mod køkkenet og kommer ud med en kande isvand og går tilbage mod stuen.

Jeg bliver taget imod og vist rundt, får introduktion til værnemidler og til processen omkring afvaskning og afspritning af de værnemidler, som genbruges og af de ting, som ikke kan smides ud, men tages ind og ud af stuerne. Selvom jeg ikke skal ind på stuerne, skal jeg håndtere urent materiale, som skal ud fra stuerne. Derfor skal jeg også indimellem bruge værnemidler og hjælpe med at rengøre ting, som er en længere proces med flere slags klude. Så får jeg den grønne vest, og jeg er klar. Vi går ned på det store kontor. Der er vagtskifte og der er mange, som møder ind her til aften. Dagvagterne er allerede gået, eller er på vej ud ad døren. Ved en tavle er der en, som kort introducerer til, hvem der skal være sammen og i hvilke grupper. Der er en del, som er her første gang ligesom jeg. Da vagtskiftet er slut, begynder aftenpersonalet at trække ud i grupperummene, nogle grupper bliver på det store kontor. Én græder lidt: »jeg har intet overblik overhovedet og jeg kan ikke komme ind i SP (sundhedsplatformen) «, siger hun til en kollega, hun lige har mødt. Senere taler jeg med hende. Hun er kommet sig lidt og har været inde hos de tre patienter, som hun har ansvar for. Hun er fra et helt andet speciale og arbejder ikke på et sengeafsnit, men med ambulante patienter. Hun fortæller, at det, der gør det svært, er ikke så meget, at hun er bange for smitte, men at hun ikke har overblik over situationen, og hvad der skal gøres hos sine patienter. "Tænk, hvis 
jeg overser noget vigtigt", siger hun forfærdet. Hun vil gerne kunne yde ordentlig sygepleje til de her patienter, som har det rigtig dårligt.

Denne fortælling om min første vagt er ikke direkte taget fra mine feltnoter, men er et sammentræk fra feltnoter og 'billeder' fra nogle af mine første vagter på COVID-afsnittet. Fortællingen er fremskrevet på den måde for både at give et indblik i præmissen for feltobservationerne i et COVID-afsnit, men også hvad vi oplevede, der særligt var på spil for sygeplejerskerne - nemlig at »kunne gøre det gode«, som en sygeplejerske udtrykker det i et af vores fokusgruppeinterviews.

Udefra set kan man sige, at bare dét, at sygeplejerskerne var der, at de prøvede så godt som de kunne, var det omverdenen forventede af dem. Men når mange alligevel var pressede, og nogle bukkede under med stres, var det ofte, fordi oplevelsen af at 'gøre det gode' ikke var til stede. Vi vender tilbage hertil, men først vender vi os mod historien - sygeplejens, hospitalets og familiens.

\section{Sygeplejen}

Verdenssundhedsorganisationen, WHO, har erklæret 2020 for Year of the Nurse and Midwife. Året skal bruges til at hylde sygeplejersker og sætte betydningen af sygepleje på den politiske dagsorden. Anledningen er, at den første sygeplejerske, som kunne fremvise epokegørende resultater af god sygepleje, Florence Nightingale, har 200 års fødselsdag den 12. maj 2020. Hun var grundlæggeren af den moderne sygepleje med kontinuerlige observationer og kvalitetsmålinger (Kjeldsen 2020). Hyldesten viste sig at komme uden WHO's opfordring hertil, en pandemi kom den i forkøbet.

Mange har påpeget sammenfaldet mellem pandemien og sygeplejens år, og hvordan pandemien har været med til at vise sygeplejerskernes værd (Nielsen et al. 2020). Men med dette sammenfald af sygeplejens år, fejringen af Florence Nightingale og pandemien kan det ikke undgås, at billeder af sundhedspersonalet som følges af overskrifter som 'frontlinje', 'helte', 'fjende' og 'kamp' dukker frem nærmest side om side med billeder af Florence Nightingale på slagmarken i Krim, hvor hun tog sig af de sårede soldater og samtidig reformerede sygeplejen bl.a. ved at dokumentere effekten af udluftning for de sårede soldaters overlevelse. Men med disse samtidige billeder forbindes sygeplejen uundgåeligt igen med 'kaldet', som Florence Nightingale identificerede sig med. Jeg forestiller mig ikke, at min afdelingssygeplejerske, hvis hun blev adspurgt dengang, ligefrem ville sige, at sygeplejen var et kald for hende. Men årsagen, til at jeg tænker, hun ikke 
vil tilskrive sig kaldet, er måske mest, fordi jeg tænker, hun vil være bevidst om, hvilke konsekvenser det vil have for arbejdsvilkår og løn, hvis hun tilkendegav, at hun ville gøre, hvad der skulle til for patientens bedste. Men i hendes beskrivelse af sit forhold til sit fag, er hun alligevel tættere på end hendes yngre medarbejdere. Hvad vores feltstudier viser er, at den moderne sygeplejerske hverken vil associere sit arbejde med et 'kald' eller med en heltegerning, som pandemien tilskriver sygeplejersken.

\section{Familien}

Florence Nightingale var en ugift kvinde, som boede på hospitalet og viede sit liv til sygeplejen - ikke som et arbejde, men som et fag. Kvinderne har op gennem historien været primæromsorgspersoner for familien, og da de kommer på arbejdsmarkedet, er det nærliggende, at kvinder bliver dem, som vælger omsorgsfag som sygeplejen. Men selv i 00'erne, hvor jeg sidder og taler med min afdelingssygeplejerske, er det fortsat kvinderne der primært tager sig af familien. Og dennes sundhed har fået ny betydning og fokus. Børns trivsel er ikke længere noget, der kan klares med ro, renlighed og regelmæssighed. Det kræver en helt anden og omfattende indsats. Heldigvis har man opdaget, at børn er kommunikerende mennesker fra fødslen og ikke nogen, som først skal til at blive det. Men med denne nye forståelse af det kompetente barn er der også kommet meget større fokus på barnets iboende potentiale, og hvad disse kan drives til under de rette betingelser som fx gennem kommunikation, den rette kost, stimulerende aktiviteter mm. Ansvaret for familiens trivsel og sundhed bliver derfor et stort og tidskrævende projekt, som dette citat i Sundhedsstyrelsens pjece "Sunde børn" illustrerer:

"Barnet har brug for, at du giver dig tid til at være sammen med det. Det er vigtigt, at I er meget sammen, og at I har det godt med hinanden, når I er sammen. Gør dig umage, når du er sammen med barnet [...]. Barnet har brug for din fulde opmærksomhed, uden at du skal lave alt muligt samtidig. Barnet udvikler sig af at være værdsat, elsket og set."

Dil Bach refererer til begrebet 'forældredeterminisme' i sin forskning om moderne forældreskab, som beskriver, hvordan forældrene gennem bestemte opdragelsesidealer og opdragelsespraksisser styrer og kontrollerer deres børn og føler et stort ansvar for at de lykkes (Bach 2015). Hun peger hermed på, hvordan ansvaret, for at de rette betingelser er til stede, i større grad hviler på forældrene i dag end 
tidligere, fx da min afdelingssygeplejerske var ung mor. Måske var min afdelingssygeplejerske, som kvinde, også ansvarlig for sin families sundhed, men opgaven var på hendes tid ikke så altomfattende et projekt.

Det er i dag stadig primært kvinder, der uddanner sig til sygeplejersker, og stadig dem som er primæromsorgspersoner i familien, og mange sygeplejersker er på nedsat tid. Derfor er arbejdstid, arbejdstidsbestemmelser, varsler, ekstra vagter mv. ikke noget, der kan være flydende og uden rammer. Med sygeplejerskernes arbejde på et COVID-afsnit var det ikke givet, at disse rettigheder og måder at arbejde på kunne eller blev overholdt, hvilket derfor havde stor betydning for plejepersonalets oplevelse af at kunne håndtere situationen.

\section{Hospitalet}

Det er ikke kun sundhedsfokus og børneopdragelse og dermed kvinders ansvar i familien, som har ændret sig og påvirker sygeplejerskers relation til deres arbejde. Også udviklingen i sundhedsvæsenet har ændret sig siden min afdelingssygeplejerske trådte ind i faget og til i dag. En udvikling, som også påvirker sygeplejerskernes relation til faget. Sygeplejefaget handler om at hjælpe patienten bedst muligt i sin situation, men sygeplejefaget skal i dag udføres i en organisation, hvor der også er mange andre hensyn at tage end den enkelte patient. Plejen skal udføres med størst mulig effektivitet, hvorfor kvalitet må sikres, måles og ensrettes bl.a. gennem retningslinjer, standarder og kvalitetskontroller og specialiserede kompetencer. Derfor indføres der ny teknologi, som skal understøtte disse krav som fx Sundhedsplatformen. Plejen ses derfor ikke kun som et fag, men også som en produktion (Lehn og Holen 2019). Lægen og sygeplejersken er ikke længere en autoritet i sin egen ret, og hospitalet styres og ledes ikke af dem, men er også en politisk styret organisation. Sygeplejerskerne er fortsat optaget af og identificerer sig med at ville 'gøre det gode', men det er ikke alene, hvad de ser som 'det gode' for den enkelte patient, som deres arbejde kan styres af.

\section{At 'gøre det gode': Pandemiens udfordringer herfor}

Sygeplejerskerne hyldes som helte, men de fleste sygeplejersker tager afstand herfra. De har et arbejde med en forpligtelse til at yde pleje og omsorg, uanset hvem patienten er, og hvad patienten fejler. Men fordi sygepleje i dag er et arbejde og 
ikke et kald, så er forpligtelsen afgrænset ikke bare i tilgangen til den, men også fastlagt som sådan organisatorisk. I heltebegrebet ligger en forventning om grænseløs forpligtelse, der kan associeres til 'kaldet'. Der ligger på den anden side også en frihed i heltebegrebet til at agere på egen hånd og gøre 'det gode' ud fra de forudsætninger, man har. 'Det gode', som et arbejde, er forbundet med særlige faglige kompetencer og i dag specialiserede kompetencer, retningslinjer, standarder, sikkerheds- og kvalitetskontrol. Sygeplejerskerne har oplevet de tre måneder, de arbejdede på et COVID-afsnit som udmattende og drænende, og mange blev sygemeldte undervejs. De fleste fordi de blev smittet, men også mange pga. stress. Stress, som blev udløst af, ikke at føle de kunne 'gøre det gode'. Situationen skabte et rum, hvor dét, de identificerede sig med, ikke kunne imødekommes. De kunne ikke udføre almindeligt gældende retningslinjer eller leve op til standarder og kvalitetskrav, og teknologien, som skulle understøtte dette, gjorde i denne situation ofte det modsatte. At ville 'gøre det gode' trådte tydeligt frem som markør ift. deres identifikation med sygeplejefaget, og det var det, der frustrerede dem og gjorde det til et udmattende arbejde. De oplevede ofte, at de ikke kunne 'gøre det gode' - enten fordi de med deres viden vidste, hvad der kunne hjælpe patienten, men rammerne ikke kunne imødekomme, at disse handlinger blev mulige, eller fordi deres viden og kompetencer var så specialiserede, at de ofte ikke kunne gennemskue eller overskue, hvad der skulle til. Så når vi andre hyldede dem for at 'gøre det gode', så var det ikke nødvendigvis noget, de følte de kunne leve op til. Men heller ikke noget de ville, for sygeplejen er ikke et kald, men et arbejde med en afgrænset forpligtelse, som de i denne situation oplevede som grænseløs. Når deres vagtplan blev ændret fra uge til uge og nogle gange fra dag til dag, så var det svært at leve op til en anden forpligtelse - nemlig den for familien.

\section{Referencer}

Bach, D. (2015). Overskudsfamilier - Om opdragelse, identitet og klasse blandt velstående familier i Nordsjælland. Århus Universitets Forlag.

Kjeldsen, S.,B. (2020). Verden hylder sygeplejersker. Sygeplejersken, (1): 46-47.

Lehn-Christiansen, S., \& Holen, M. (2019). Logics of care in clinical education. Journal of Organizational Ethnography, 8(3), 268-278.

Nielsen, D. et al. (2020) Cultural Perspectives and Nurses Reactions on the Corona Pandemic: A Critical View From Denmark. Journal of Transcultural Nursing. 